\section{Multidisciplinary \\ SCIENTIFIC JOURNAL OF \\ MARITIME RESEARCH}

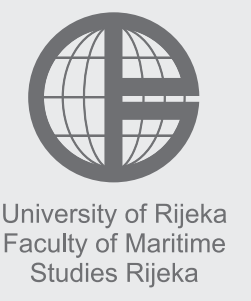

Multidisciplinarni

znanstveni časopis

POMORSTVO

\title{
Liability of the multimodal transport operator - the case of Kosovo
}

\author{
Nexhat Jashari \\ Kosovo Academy for Public Safety-Faculty of Public Safety, Vushtrri, Kosovo, e-mail: njashari@hotmail.com
}

\section{ABSTRACT}

This paper gives a particular attention to the handling of the multimodal transport operator's liability in view of the new legislation in Kosovo, in terms of comparison with international legislation. From the research carried out in this area of transport, it has been found that, over the last decades, the international transport of goods has become more sophisticated and effective, and has increased rapidly because of the increased use of containers. Containers have advanced the flexibility to focus more on an integrated movement of goods instead of the movement specifically associated with a certain mode of transport. Unfortunately, this technical flexibility has been accompanied by a severe rigidity in the legal field in Kosovo as well. Although the transfer of goods from one type of transport to another type of transport has been greatly facilitated as a result of the container revolution, developments in the area of international and Kosovo legislation in the field of transport have not followed this pace. The recommendations on the necessity of a better regulation of the liability of the multimodal transport operator in the new legislation in Kosovo have been given at the end of this paper.
\end{abstract}

\section{ARTICLE IN FO}

Review article

Received 9 May 2017

Accepted 5 June 2017

Key words:

New legislation

Law on obligation relationships

Kosovo

Multimodal transport operator

\section{Introduction}

In order to address the liability of the multimodal transport operator, an analysis of the current state of plays in the field of legal regulation of multimodal transports, and in particular of the multimodal transport operator liability regime has to be done. Numerous authors and scientific institutions have carried out specific studies regarding the current framework of international multimodal transport law by taking into account the previously mentioned specificities regarding the multimodal transport. The legal framework for multimodal transport is made up of a collection of conventions dealing with the transport of goods by just one special way of transport, while a convention of transport, which deals with multimodal transport, is still lacking a fair finding [2]. Various efforts have been made to create an international legal instrument to regulate this type of transport; however, political and economic disagreements have prevented the success in this area. The absence of a multimodal transport convention is much more seen when attempts are made to establish the legal regime in force for a multimodal transport contract, in situations related to the localized damage. Without an international instrument, carriers cannot always be sure which accountability regimes will apply to their activities, not in relatively simple cases with regard to localized damage case. The ascertainment of the regime in force is not an unnecessary luxury, but the existing regimes vary greatly when it comes to the base of the carrier's liability or to their extent. The most visible differences are those that relate to the basis of the operator's liability in case of damage, compensation value, which accountability system will be implemented etc. With the new draft instrument, which was originally intended to be made no more than a doorto-door instrument, CMI and UNCITRAL are trying to fill the international multimodal gap. The liability of the multimodal transport operator is complex and overwhelming, due to the fact that the multimodal transport operator carries out important and sensitive work, according to the order and on behalf of his requester. His legal position in the multimodal transport contract makes him even more responsible due to the fact that the multimodal transport 
operator is also responsible for the work of all other persons who have been engaged by him. The following issues address the liability of the multimodal transport operator:

- The multimodal transport operator's liability system;

- Responsibilities of the multimodal transport operator for damage, shortage, or loss of goods;

- Responsibilities of the multimodal transport operator for the delay in the delivery of the goods;

- Responsibilities of the multimodal transport operator for the persons who are engaged by him to carry out the work when doing the transport;

- Margin of liability of the multimodal transport operator.

\section{Multimodal transport operator's liability system}

The previous attempts to create an international instrument regulating multimodal transport incorporated different means to fit in with the existing profusion of international and national transport arrangements. The two main alternatives are known as the network and uniform approach. Due to the extremity of the consequences when these opposites are implemented in their pure form, most of the past efforts to create a treaty contained a compromise. This compromise is appropriately called the modified approach [4].

\subsection{Liability of the transport operator based on the road network system}

Under this liability system, the multimodal transport operator shall be liable according to the legal rules applicable to the part of the transport route where the caused damage has occurred. This implies that, according to this basis on the liability of the multimodal transport operator, the legal right shall be applied for each part of the road, respectively the legal rules for the respective transport and traffic branch either rail, road, or sea transport, depending on which part of the transport route the damage has occurred. The network liability system of the multimodal transport operator has its advantages and disadvantages, which will be presented below, indicating the reasons as why the best application for legal science and business practice will be considered [9].

The advantages of the liability system, according to the road network, depend on the fact that in each section of the transport route the specific right of the transport branch is implemented, in the rules established for the accountability system and with an enriched court practice. According to this system, the operator shall be familiar with the place and time of the caused damage. However, some problems may arise with regard to the principles of liability of the operator, when the time and place of the occurrence of the event results in causing the damage, or the time and place cannot be determined. The valid legal rules of any transport branch are not affected, and thus the misinterpretations of the rules and disputes are avoided.

The multimodal transport operator has legal certainty that the compensation, that as a responsible person has paid the user, has the right to reimbursement through the right of regress of the carrier who caused the damage, because both of them respond according to the rules on the same branch of transport.

The Civil Obligations Act stipulates that the carrier, who entrusts to another carrier the performance of the transportation of the shipment, entirely or partly, remains further responsible for its transport from pick up to delivery, but has the right to reward from the carrier to whom the shipment has been entrusted. The international convention and the national law of the state, which has not yet ratified the convention, avoid the possibility of conflict or confrontation. The place and time of the event when the damage is caused, is particularly difficult to determine when the transportation of goods is done through the container transport system, because, when considering the nature and the techniques of this transport, the determination of the condition of the goods, namely the determination of the place and time when the damage is caused is difficult, due to the fact that the goods cannot be observed , and the eventual damage is noticed only after the completion of the transport i.e. with the opening of the containers [9].

The flaws of the network liability system lie in the fact that the multimodal transport specifications are such that the operator's liability moves depending on which part of the transport route the damage has occurred. This system is impossible to be implemented in cases where it is impossible to determine the place where the damage was caused, "undocumented damage", and in this case, the branch's right to be applied, for the liability of the multimodal transport operator, cannot be assigned.

Since the multimodal transport operator is responsible from the moment he receives the goods from the consignor to the delivery of the goods to the recipient in the accountability system, and, according to the road network, the problem may arise with regard to the determination of the liability of the legal entities that perform different jobs in the multimodal transport, except transport works themselves, such as loading, unloading, storage, measurement, counting etc. In addition, the problem of the assignment of delay liability may be announced when the part of the roadway where the delay occurred is unknown. In practice, the multimodal transport operator does not convey the goods during transport; the transport user often cannot prove at which stage of transport the damage was caused. This is most often expressed in cases when the goods being transported are sealed in stamped containers, which is the most common practice of multimodal transport, since the damages are noticed only after the transport has been completed, after the delivery of the goods to the recipient. The problem and other deficiency of the grid system is the damage caused to some participating branches, because, in such a case, it is not known, which 
legal regime of the branch will be applicable. Therefore, taking into account the above-mentioned, the professional literature says that this system is not as safe and convenient for participants in the multimodal transport. Despite the shortcomings of the network system, it is often encountered in the national legislation of the states, while in international law it is combined with the unity system, thus creating a new system known as a mixed system of legal regulations of the multimodal transport [9].

\subsection{System of unique responsibility}

The objective of any new international convention should be to unify or harmonize and simplify the existing law on the subject it intends to regulate. There had been no international framework of unimodal carriage conventions in existence; this objective would undisputedly have been served by a uniform liability regime where multimodal transport is concerned [6]. A uniform liability system subjects the entire multimodal transport contract to the same rules of liability, irrespective of the modes of transport that are actually used to perform the carriage. In a pure uniform liability system, the same set of rules applies irrespectively on the stage of transport during which loss, damage or delay occurs [3].

The system of a unique liability exists when the multimodal transport operator is liable for the damage under specific material law, valid only for multimodal transport, irrespective of existing regimes in other transport branches for the carrier's liability, from the moment of the receipt of the goods to the delivery of the goods to the recipient.

The convent provides that "The liability of the multimodal transport operator, for the goods under this Convention, covers the period from the time he takes the goods in his charge to the time of their delivery" [7]. The position of the legal doctrine in the field of multimodal transport is supported and strongly argued by professor Zelenika that according to this system of liability the multimodal transport operator is responsible for all damages that will be caused in the multimodal transport with the actions defined in the contract for the multimodal transport. The multimodal transport operator shall be liable to the user of this transport for the damage caused during the multimodal transport of the goods, exclusively in accordance with the rules for multimodal transport. This also means that the multimodal transport operator is responsible for the work of all persons engaged in multimodal transport and for the damage or loss and for the delay in delivery, from the moment when the goods are accepted for transport to the moment when the goods are delivered to the recipient of the goods [9].

This position of the doctrine is strengthened even more when considering the provisions of the Convention, which has decisively defined the liability of the multimodal transport operator as follows "... the multimodal transport operator shall be liable for the acts and omissions of his servants or agents, when any such servant or agent is acting within the scope of his employment, or of any other person of whose services he makes use for the performance of the multimodal transport contract, when such person is acting in the performance of the contract, as if such acts and omissions were his own" [7]. Unlike the networking system of responsibility, which in multimodal transport sees only a batch of multi-branch transports that continue one after the other in the destination country, the unity system is established in the sense of multimodal transport as a unique act in fulfilling each contract, separately from the contracts of transport branches, with the operator as the responsible person for the entire transport.

The Civil Obligations Act, although it does not contain a provision that would assign the liability of the multimodal transport operator, contains a provision for the carrier's liability in general, in the contract for the carriage of goods, so that "A carrier that entrusts the complete or partial transport of a consignment accepted for transport to any other carrier shall continue to be liable for the transport there of from acceptance to delivery, but shall have the right to reimbursement from the carrier entrusted with the consignment" [1]. This system applies only in relation to the transport operator with the users while the network system is valid for the relations between the operator and the sub-carrier. This means that each carrier is liable to the operator who has compensated the transport user for the damage, according to the rules of the transport branch in which the damage occurred, except in the case when the contract foresees something else.

\subsection{The modified system}

The modified system is a compromise between the uniform and the network system, which tries to combine the best elements of both. A modified liability system essentially seeks to provide a middle-way between the uniform and the network approach. Various arrangements are possible, making a system more uniform or more networks oriented. In practice, a great deal of use is being made of this kind of system in the form of contractual standard rules like the UNCTAD/ICC Rules [4].

\section{Responsibilities of the multimodal transport operator for the damage, shortage or loss of goods}

The responsibility of the multimodal transport operator for the damage, shortage or loss of goods, is regulated by the national and international legislation by providing strict rules on this matter. The United Nations Convention on the International Multimodal Transport of Goods of 1980 stipulates that the multimodal transport operator is liable for the damage caused by the loss or damage of the goods as well as the delay in the delivery of the goods while the goods were in the possession of the operator, unless the multimodal transport operator proves that he or his employees or agents or any other person acting for the purpose of carrying out the activities for the fulfilment of the contract, for which omissions the operator is liable, 
as if he has caused those omissions himself, that has taken all the necessary measures to avoid the occurrence and its consequences [7]. This means that the operator responds, to the principle of liability under the guilty plea and if he/ she wishes to be released from liability, he/she must prove that he/she is not guilty of loss, damage, or delay in the delivery of the goods and that the evidence must be compelling, reliable and in writing [9]. The Civil Obligations Act provides that "The carrier shall be liable for any loss of or damage to the consignment during the time between accepting and delivering, unless it is a consequence of the action of the entitled person, an attribute of the consignment, or external causes that could not be anticipated and could not be avoided or averted". [1]

\section{Responsibilities of the multimodal transport operator for the delay in the delivery of the goods}

The Civil Obligations Act although does not contain any specific provision regarding the liability of the multimodal transport operator, it, however, deals with the liability of the transporters, which could also be applied to the liability of the multimodal transport operator. The law states that the carrier is liable for the damage caused by a delay, unless the delay is caused by any fact that excludes his liability for the loss or damage to the goods.

Pursuant to the United Nations Convention on the International Multimodal Transport of Goods, the multimodal transport operator shall be liable for the damage caused by the loss or damage of the goods and the delay in the delivery of the goods if the event which caused the loss, damage or delay in the delivery of the goods occurred when the goods were in the possession of the multimodal transport operator, unless the multimodal transport operator proves that he, his staff, agent or any other third person mentioned in Article 15 of the Convention have undertaken all the measures that were necessary to avoid the event and its consequences [7].

The United Nations Convention on the International Multimodal Transport of Goods has set the conditions when it will be considered that the multimodal transport operator has been delayed, it is still not easy and simple to determine, i.e. to set the delay in the delivery of the goods to the recipient. It is stipulated in the convention that "Delay in delivery occurs when the goods have not been delivered within the time expressly agreed upon or, in the absence of such agreement, within the time which it would be reasonable to require of a diligent multimodal transport operator, having regard to the circumstances of the case" [7].

Thus, the United Nations Convention on the International Multimodal Transport of Goods, stipulates that the delay implies a situation where the goods have not been delivered within the time-limits laid down in the contract or if there were no such arrangements within the period which normally may be required by the regular multimodal transport operator taking into account the circum- stances of the case. The Convention provides that, if the goods have not been delivered within 90 consecutive days following the date of delivery, the claimant may treat the goods as lost [7].

The Civil Obligations Act, regarding the delay, has foreseen that: "The carrier shall be liable for the damage incurred because of a delay, unless the reason for the delay is any fact that excludes the carrier's liability for the loss of or damage to the thing." [1].

The multimodal transport operator shall be liable for the delay in the delivery of the goods, respectively the goods according to the presumed fault principle and he/she wishes to be relieved of such liability, he/she shall prove that he/she is not guilty for the delay in the case of delivery of the goods, which means that the operator is in a position to prove the real facts regarding the delay and also to prove that he/she has acted with professionalism, liability and has protected the interests of the ordering party [9].

\section{Liabilities of the multimodal transport operator for the persons engaged in carrying out transport operations}

Under the United Nations Convention on the International Multimodal Transport of Goods, the multimodal transport operator shall be liable for the acts and omissions of his servants or agents, when any such servant or agent is acting within the scope of his employment, or of any other person of whose services he makes use for the performance of the multimodal transport contract, when such person is acting in the performance of the contract, as if such acts and omissions were his own [7]. The Civil Obligations Act, although it does not contain a special norm for multimodal transport, it provides the liability of the transport operator for the persons who are engaged and have carried out certain transport operations upon request or his/her order.

The Civil Obligations Act stipulates that: "The carrier shall be liable for persons working during the transport at the carrier's orders" [1].

The convention determines that "Where fault or neglect on the part of the multimodal transport operator, his servants or agents or any other person referred to in article 15 combines with another cause to produce loss, damage or delay in delivery, the multimodal transport operator shall be liable only to the extent that the loss, damage or delay in delivery is attributable to such fault or neglect, provided that the multimodal transport operator proves the part of the loss, damage or delay in delivery not attributable there to" [7]. Based on the provision cited in the Convention when the issuance, respectively the fault or neglect of the multimodal transport operator, its employees, agents or other persons are interlaced with other causes that cause the loss, damage or delay in delivery, the multimodal transport operator shall be liable only if such loss, damage or delay in the delivery of the goods may be described as an error or negligence and if the multimodal transport opera- 
tor proves the height of the part that it is lost or damaged, or of the delay of the delivery which can be described to him/her (multimodal transport operator).

\section{The limit of the liability of the multimodal transport operator}

The limit of the liability of the carrier represents the essence of the problem of liability both in the road transport and in other transport branches [5]. Different authors also address the limitation of liability in sea transport when dealing with the limits of liability of the shipowner, port manipulator [8]. The United Nations Convention on the International Multimodal Transport of Goods by special provisions has also regulated the issue of limiting the liability of the multimodal transport operator [7]. According to this convent, when the multimodal transport operator is liable for loss resulting from the loss of or damage to the goods, his liability shall be limited to an amount not exceeding 920 units of account per package or other shipping unit or 2.75 units of account per kilogram of gross weight of the goods lost or damaged, whichever is the higher.

The Civil Obligations Act that: "Provisions of the contract of carriage, the general terms and conditions of transport, tariffs or any other legal act that limit such liability shall be null and void." [1]. "However a provision by which the maximum sum of compensation is stipulated in advance under the condition that it is not in clear disproportion to the damage shall be valid" [1].

I consider that the provisions of the Civil Obligations Act, although do not mention the multimodal transport operator, are applied in such a way that the contracting parties do not exclude the limits of liability set out in this Convention by reducing the limit of liability.

\section{Conclusion}

As has already been said, it can be concluded that the present legal framework for the International Multimodal
Transport of Goods is made up of a collection of conventions that deal with the transport of goods by only one particular mode of transport.

The national legislation in Kosovo, however, contains rules regarding the liability of the carrier, yet it cannot fill the void in relation to the specific reports that are created under the international multimodal freight transport contract. The legal regulation of the international multimodal freight transport is not only a requirement but also a necessity, and the Government, respectively the Ministry of Infrastructure, should treat this issue with priority, which should without delay initiate procedures for drafting a special law on the multimodal transport.

\section{References}

[1] Civil Obligations Act, Law no. 04-L-077, Official Gazette of the Republic of Kosova, No. 16, 19 Juni 2012, Pristina.

[2] Eftestöl-Wilhelmsson, E. (2007) EU intermodal transport and carrier liability-content and context. Scandinavian Institute of Maritime Law, University of Oslo, Yearbook 2007.

[3] Haak, K.F.: The Harmonization of Intermodal Liability Arrangements, ETL (2004):11-51.

[4] Hoeks, M. (2010) Multimodal Transport Law: The law applicable to the multimodal contract for the carriage of goods. Kluwer Law International.

[5] Radionov, N.: Ograničenje odgovornosti prijevoznika u cestovnom prijevozu stvari, Zbornik, PFZ, 48(3), 1998.

[6] UNECE, Inland Transport Committee, Working Party on Combined Transport, 'Possibilities for reconciliation and harmonization of civil liability regimes governing combined transport', Overview of provisions in existing civil liability regimes covering the international transport of goods, Thirty-third session, 10-11 April 2000.

[7] United Nations Convention on International Multimodal Transport of Goods, Geneva, 24 May 1980.

[8] Vasilj, A. and Bošnjak, M. (2011) Sustavi općeg ograničenja odgovornosti u pomorskom pravu - potreba unifikacije pomorskog prava. Zbornik radova Pravnog fakulteta $u$ Splitu, 48(3), pp. 549-576.

[9] Zelenika, R. (2006) Pravo multimodalnoga prometa, Sveučilište u Rijeci, Ekonomski Fakultet u Rijeci. 